\title{
Post-travel screening of symptomatic and asymptomatic travelers
}

\author{
Krzysztof Korzeniewski ${ }^{1,2}$ \\ ${ }^{1}$ Department of Epidemiology and Tropical Medicine; Military Institute of Medicine, Warsaw, Poland \\ ${ }^{2}$ Department of Occupational, Metabolic and Internal Diseases, Institute of Maritime and Tropical Medicine, \\ Medical University of Gdansk, Poland
}

\begin{abstract}
Until last year, terrorism, economic instability, poverty and natural disasters were considered the major threats to humans globally. Infectious diseases were seen as a minor problem. This, however, changed in 2020 when the global COVID-19 pandemic broke out and a new danger emerged. The latest events generated a lot of discussion on health hazards associated with international tourism and uncontrolled spread of pathogens across the borders. The major health problems of travelers to developing countries with harsh environmental conditions and endemic infectious diseases include gastrointestinal disorders, dermatoses, respiratory infections and fevers of unknown origin. A medical interview by an experienced physician is the foundation of the post-travel screening process both in symptomatic and asymptomatic travelers; the interview should focus on identifying exposure to risk factors (endemic infectious diseases, failure to adopt disease prevention measures, consumption of food or water from unsafe sources, insect bites, animal bites, travelling in large groups, unsafe sex with casual partners). While physical examination (identification of abnormalities) and diagnostic tests (identification of pathogens) can be useful for detecting illnesses and asymptomatic infections as well as assessing the general health condition of a patient, including his immune system. The aim of the article is to provide information on the post-travel screening process in symptomatic and asymptomatic travelers who have returned from areas with harsh climate conditions and low sanitation standards.
\end{abstract}

(Int Marit Health 2020; 71, 2: 129-139)

Key words: travelers, risk factors, diseases, diagnostics

\section{INTRODUCTION}

According to the World Tourism Organization (UNWTO), there were 1.5 billion international tourist arrivals worldwide in 2019. The gradually increasing number of international tourist arrivals seen in recent years $(+6 \%$ in 2017 , $+6 \%$ in $2018,+4 \%$ in 2019 ) was predicted to reach a spectacular level of 1.8 billion in 2030. All regions saw a rise in tourism in 2019 compared to the previous year (Asia and the Pacific $+5 \%$, Europe and Africa both $+4 \%$, the Americas $+2 \%)$. According to the estimates, a growth of $3-4 \%$ was predicted for 2020 [1]. However, the COVID-19 pandemic has brought the tourist industry to a halt, and the earlier forecasts had to be revised. Most experts believe that the domestic demand for travelling and travel services is likely to rise faster than international tourism; whereas the international demand is predicted to grow faster in Africa and the Middle East, where the number of active SARS-CoV-2 cases and COVID-19 deaths is much smaller compared to the European countries or North America [1]. The restrictions imposed on international air transport, travel agencies, hotels and restaurants will certainly have a significant impact on the economies of many countries, especially those in which tourism accounts for a significant proportion of Gross Domestic Product. According to the UNWTO estimates, the number of international tourist arrivals may drop by $60-80 \%$ in 2020 (compared to 2019; a loss of 850 million to 1.1 billion) [2]. The most visited countries by tourists in the world have reported both a very

Prof. Krzysztof Korzeniewski, MD, PhD, Chairman of the Polish Society of Maritime, Tropical and Travel Medicine, Powstania Styczniowego St. 9B, 81-519 Gdynia, Poland; Military Institute of Medicine, Head of the Department of Epidemiology and Tropical Medicine, Szaserów St. 128, 04-141 Warszawa, Poland, e-mail: kkorzeniewski@wim.mil.pl 
Table 1. The most visited countries by tourists versus number of detected SARS-CoV-2 infections and COVID-19 deaths, 29 May 2020

\begin{tabular}{llll}
\hline Country & $\begin{array}{l}\text { Tourist arrivals in millions } \\
\text { in 2018 [3] }\end{array}$ & SARS-CoV-2 infections [4] & COVID-19 deaths [4] \\
\hline France & 89 & 186,835 & 28,714 \\
Spain & 83 & 285,644 & 27,121 \\
USA & 80 & $1,793,530$ & 104,542 \\
China & 63 & $82,995 *$ & $4,634^{*}$ \\
Italy & 62 & 232,248 & 33,229
\end{tabular}

*According to Chinese sources; USA - United States of America

large number of SARS-CoV-2 cases and COVID-19 deaths (Table 1) [3, 4].

The countries whose economies almost entirely rely on tourism, e.g. the Caribbean or the Pacific Islands, are likely to be affected by a serious economic crisis. But the global downturn may also affect the European Union countries, where the tourism industry offers employment to $12 \%$ of the economically active people and generates an income of 400 billion euro per year. Some countries, e.g. Greece or Croatia have been considering the introduction of the so-called 'tourist corridors' linking the popular resorts with countries least affected by the pandemic or those where the SARS-CoV-2 epidemic has been successfully contained, without a mandatory 14-day quarantine upon arrival. It is also planned to introduce COVID safety certificates for the re-opening hotels, restaurants and other tourist facilities to ensure that re-opening those businesses will not increase the risk of spreading COVID-19. Some countries are also discussing the introduction of 'immunity passports', a digital or paper document that will certify that an individual has been infected with SARS-CoV-2 and is immune to COVID-19 [5]. Turkey is planning to re-open its borders only for foreign tourists with a negative SARS-CoV-2 test result; visitors will be required to present the test result upon arrival. The Canary Islands in collaboration with the Department of Innovation and Digital Transformation (UNWTO) are working on a new project aimed at the introduction of digital health passports (a mobile phone application developed by $\mathrm{Hi}+\mathrm{Card}$ ) for all tourists visiting the islands this summer. The application will contain the visitors' medical data certifying they are free of COVID-19 and will allow the authorities real-time tracking of travelers (for which the travelers grant their consent when installing the application). All these measures are meant to rebuild the tourism industry, which is a major branch of the global economy, as fast as possible.

Until 2019, it seemed that the major travel-associated threats to humans were terrorism (the Middle East, North Africa), socio-economic instability (Venezuela) and natural disasters (earthquakes and floods). Infectious diseases were further down the list, next to petty crimes or traffic accidents. In 2018, the World Health Organization (WHO) published a list of priority diseases which are a top threat to public health globally because of their pandemic potential, the first on the list were viral hemorrhagic fevers (Ebola, Marburg, Lassa, Crimean-Congo), coronavirus infections (MERS, SARS) and Disease X (a placeholder name for currently unknown disease, possibly a viral zoonosis) [6]. In January 2020, Disease X turned out to be COVID-19, an infection which originated in the Chinese province of Hubei and its capital, Wuhan and caused a global pandemic. Two years ago, the WHO stressed how important it is to improve the quality of healthcare systems around the world to be able to control the possible future outbreak and prevent the spread of diseases. Will the ongoing COVID-19 pandemic raise public awareness of the importance of post-travel health assessment, especially in those travelers who are returning from countries where infectious diseases are endemic? Now seems to be the right time to initiate discussion on travel-related health risk factors and uncontrolled spread of pathogens across the borders. The aim of the article is to provide information on the post-travel screening process in symptomatic and asymptomatic travelers returned from areas with harsh climate conditions and low sanitation standards.

\section{INFECTIOUS DISEASES IMPORTED BY POLISH TRAVELERS}

The Polish National Institute of Public Health - National Institute of Hygiene, the Department of Epidemiology and Surveillance of Infectious Diseases publishes a report on cases of infectious diseases and poisonings in Poland every 2 weeks. The report includes both domestic and imported cases. Influenza and influenza-like illness are at the top of the list: a total of $4,789,827$ cases were reported in 2019 (5,239,293 in 2018) [7]. Unfortunately, most of these diagnoses are not confirmed by a laboratory test and therefore a large proportion of illnesses manifesting with similar clinical signs (fever, osteoarticular and muscle pain, general weakness) may be mistakenly reported as influenza or parainfluenza. These may include imported tropical diseases such as malaria or arboviral infections (dengue, chikungunya, zika). According to the reports, there 
were 25 confirmed cases of imported malaria, 55 cases of dengue, 2 cases of chikungunya and zero cases of zika in 2019 (in 2018, the number of confirmed cases was reported to be $28,30,0,1$ infections, respectively) [7]. The actual number of other tropical infections (e.g. schistosomiasis, filariases, leishmaniases) or cosmopolitan diseases which are endemic in developing countries (ascariasis, trichuriasis, hookworm) in returned travelers is not known. There are two major reasons for this - the first is the lack of testing, and the second the lack of obligation to report the diseases to competent authorities. As was mentioned before, Polish patients are rarely screened for tropical diseases (even if a patient who has returned from a tropical country reports fever of unknown origin, post-travel screening is hardly ever recommended since Polish laboratories do not offer test panels for the detection of tropical diseases). Therefore, it is likely that some imported tropical infections may be misdiagnosed as cosmopolitan diseases. In such cases patients will only receive symptomatic treatment, and the real etiological factor will never be discovered. Asymptomatic carriers are especially problematic from a public health perspective because they can transmit the infection to other people without knowing it. Previous studies by the author, which involved groups of Polish soldiers deployed on military missions to Central Asia and the Middle East, demonstrated significant numbers of asymptomatic infections caused by intestinal parasites [8] and hepatitis E virus (HEV) [9].

\section{COMMON HEALTH PROBLEMS OF INTERNATIONAL TRAVELERS}

It has been estimated that as many as $43-79 \%$ of travelers from European or North American countries are likely to experience a travel-related health problem during or after travel to a developing country [10]. Most of these travelers will have mild symptoms, while $1-5 \%$ will seek medical care from a health care provider. A majority of travel-related conditions have a short incubation time with symptoms manifesting during or shortly after travel; there are some diseases, however, which have much longer incubation periods and whose symptoms tend to manifest weeks or even months after returning home. Travelers who have recently returned from a country where infectious diseases are endemic should inform their health care provider of this fact. A post-travel medical interview should primarily focus on the following questions: vaccinations received before travel; compliance with antimalarial chemoprophylaxis before, during and after travel; the use of insect repellents during travel; disease symptoms which occurred during travel and medications taken to treat the symptoms; countries visited, the length of stay, the type of accommodation; travel to large population centers; consumption of the local food; insect bites (mosquitoes, sand flies, ticks); animal bites; unsafe sex with casual partners (local people or other travelers); surgical procedures, blood transfusions, injections, tattooing [11-14]. The most common health conditions in travelers to destinations with harsh environmental conditions and endemic infectious diseases include gastrointestinal disorders, dermatoses, respiratory illnesses and fevers of unknown origin [15].

\section{GASTROINTESTINAL DISORDERS}

The most common gastrointestinal conditions in travelers include acute diarrheas (defined as a minimum of three loose stools within $24 \mathrm{~h}$ or an increase in stool weight $>200 \mathrm{~g} /$ day associated with increased stool liquidity, lasting for no longer than 14 days; mainly of bacterial [Escherichia coli, Salmonella, Shigella, Campylobacter] or less often of viral etiology [Norwalk, adenoviruses and rotaviruses]). These are commonly referred to as travelers' diarrhea (symptoms usually resolve spontaneously after a few days). Some returned travelers, however, may experience persistent diarrheas (lasting longer than 14 days), which are usually of parasitic etiology (Giardia intestinalis, Cryptosporidium parvum, Entamoeba histolytica). The diagnosis of suspected bacterial diarrheas is based on conventional microbiological methods (stool culture). The test is recommended if blood or pus is present in the stool, also in febrile or immunodeficient patients and patients with chronic conditions. The diagnosis of viral diarrheas relies on molecular methods (polymerase chain reaction [PCR]), while the gold standard for the diagnosis of parasitic diarrhea is the multiple fecal tests, i.e. examining of stool (at least three samples) by light microscopy, preferably using concentration techniques (sedimentation for the detection of protozoa and flotation for the detection of helminths). Persistent diarrheas should be differentiated from non-infectious or post-infectious conditions, such as the malabsorption syndrome or the irritable bowel syndrome. The malabsorption syndrome caused by impaired absorption of food nutrients in the gastrointestinal tract is often associated with celiac disease (gluten-sensitive enteropathy), cystic fibrosis, chronic pancreatitis or pancreatic cancer, status post gastrectomy, enzymatic deficiencies (lactase deficiency causing lactose intolerance, sucrase-isomaltase deficiency - sucrose intolerance aldolase deficiency - fructose intolerance). Irritable bowel syndrome, on the other hand, is an idiopathic gastrointestinal disorder of unknown etiology characterized by abdominal pain, flatulence and defecation disorders (diarrhea or constipation) $[11,14,16]$.

\section{DERMATOSES}

The most common skin problems found in returned travelers include allergic reactions to insect bites (scratching the lesions may cause a secondary pyoderma, erosions or 
ulcerative lesions), allergic rash, superficial skin lesions (epidermal abrasion, animal bites or scratches, sunburns, exposure to marine animals, e.g. jellyfish stings), pyodermas (folliculitis, furuncles, abscess), fungal infections. Tropical dermatoses, such as an arboviral infection presenting with a skin rash (dengue, chikungunya, zika), cutaneous larva migrans or myiasis are rarely seen in travelers. The diagnosis of skin lesions is based on identifying the type of lesion (maculopapular or papular rash, nodules, vesicular/bullous rash, pustules, erosions/ulcers), its location (hairless or hairy skin, armpits, groins, joints), etiological factor (insect bites, exposure to sun, exposure to pathogens - viruses, bacteria, parasites, fungi) and associated symptoms (pruritus, pain, burning sensation, fever) [17].

\section{RESPIRATORY INFECTIONS}

The most common respiratory illnesses diagnosed in returned travelers include upper respiratory tract infections (a cold, pharyngitis, tonsillitis, sinusitis). Lower respiratory tract infections (e.g. pneumonia) are less common but present with more pronounced signs and symptoms (fever, chest pain, cough, dyspnea) and therefore may require in-hospital treatment. Respiratory illnesses are most often caused by viruses (influenza viruses, adenoviruses, rhinoviruses, coronaviruses) and bacteria (Streptococcus pneumoniae, Mycoplasma pneumoniae, Haemophilus influenzae, Chlamydophila pneumoniae, Legionella pneumophila). Tropical pathogens are rarely responsible for respiratory infections in travelers. Mass infections may occur during organized tours, in hotels, on cruise ships or passenger aircrafts (droplet or airborne transmission). The diagnosis of a respiratory illness is based on the identification of the etiological factor either by molecular methods (viruses) or standard microbiological techniques, e.g. culture (bacteria). The biological material used for testing is usually a sputum or nasopharyngeal swab sample, a bronchoscopy sample or tracheal aspirate samples; the standard imaging method for the diagnosis of respiratory illnesses include a sinus or a chest X-ray [18].

\section{FEVERS OF UNKNOWN ORIGIN}

Malaria is a common cause of fever in travelers returning from tropical or subtropical destinations (infection with Plasmodium parasite through a bite of an infected mosquito). Other common travel-related febrile illnesses include dengue, chikungunya, zika (arboviral infections transmitted by mosquitoes), viral hepatitis $A$, typhoid fever (transmitted through the fecal-oral route) and rickettsioses (transmitted by lice, fleas, ticks, mites). Febrile illnesses may be of non-tropical origin as well and be a sign of a respiratory or a urinary tract infection; fever may also be an accompanying symptom of many dermatoses, e.g. burns. A febrile patient is likely to have other symptoms as well (headache, general weakness, muscle and joint pain, gastrointestinal disorders, shin rash, conjunctivitis) which may be important for the differential diagnosis; most febrile illnesses have a short incubation period and tend to manifest within 4 weeks after traveler's return. Some conditions, however, have longer incubation periods and can manifest themselves many weeks after return; these include Plasmodium vivax malaria, tuberculosis or viral hepatitis. The onset of fever may be gradual and eventually reach a very high level and be associated with bradycardia (as in typhoid), or abrupt as in dengue. Malaria is typically characterized by a sudden onset of fever which is then recurring in cycles. In Plasmodium vivax and $P$. ovale infections, fever paroxysms occur periodically every 48 hours, in $P$. malariae infection - every 72 hours. Fever paroxysms in $P$. falciparum malaria are irregular and elevated body temperature of varying degree can persist all throughout the duration of the symptomatic disease. When diagnosing a febrile patient who has returned from a tropical destination, malaria should be ruled out first (the thick and thin blood smears) before proceeding with further tests. It is then recommended to perform serological tests to rule out arboviral infections (dengue, chikungunya, zika), tests to detect infections which are endemic in the visited part of the world (HAV, HEV), blood count with differential, liver enzymes levels, urinalysis, C-reactive protein (CRP), a chest $X$-ray, stool microscopy (detection of parasites) and, in justified cases, blood, urine and stool culture [19].

Most travel-related illnesses tend to manifest within a few weeks after traveler's return (Tables 2, 3). Some conditions, however, have longer incubation periods and their symptoms may manifest 6 or more weeks after coming back home. For this reason a medical interview forms the basis of post-travel assessment. A febrile illness occurring more than 3 weeks after return almost certainly rule out dengue or rickettsioses. A late onset of symptoms may be suggestive of visceral, cutaneous or mucocutaneous leishmaniasis, chronic Chagas disease, chronic brucellosis, malaria or schistosomiasis. The accuracy of a clinical diagnosis and the effectiveness of treatment will much depend on a patient himself. In order to establish an accurate diagnosis, a physician needs to know of all the risk factors a patient might have been exposed to during travel (Table 4). If patients conceal or omit any significant information from their health care provider, it will be more difficult for a physician to make an accurate diagnosis and implement effective treatment $[11,20,21]$.

\section{TYPES OF EXAMINED TRAVELERS}

Post-travel assessment is primarily recommended to:

- symptomatic travelers who experience symptoms of an infection on their return or within three months after return, especially if they experience fever, persistent 
Table 2. Incubation period and disease symptoms [20]

\begin{tabular}{|c|c|c|}
\hline $\begin{array}{l}\text { Incubation } \\
\text { period }\end{array}$ & Symptoms & Disease \\
\hline$<2$ weeks & Fever + non-specific symptoms & $\begin{array}{l}\text { Malaria, dengue, chikungunya, zika, campylobacteriosis, salmonellosis, shigellosis, } \\
\text { African trypanosomiasis, leptospirosis, typhoid fever }\end{array}$ \\
\hline$<2$ weeks & Fever + coagulation disorders & Invasive meningococcal disease, leptospirosis, malaria, viral hemorrhagic fevers \\
\hline$<2$ weeks & Fever + neurological symptoms & $\begin{array}{l}\text { Malaria, typhoid fever, rickettsioses, invasive meningococcal disease, rabies, } \\
\text { African trypanosomiasis, poliomyelitis, encephalitis and/or meningitis }\end{array}$ \\
\hline$<2$ weeks & Fever + respiratory symptoms & $\begin{array}{l}\text { Influenza, COVID-19, common cold, streptococcal pharyngitis/pneumonia, } \\
\text { legionellosis, Q fever }\end{array}$ \\
\hline$<2$ weeks & Fever + skin lesions & $\begin{array}{l}\text { Rubella, varicella, measles, herpes simplex, dengue, chikungunya, zika, rickettsioses, } \\
\text { typhoid fever, HIV infection }\end{array}$ \\
\hline 2-6 weeks & $\begin{array}{l}\text { A variety of symptoms: fever } \\
+ \text { neurological or respiratory } \\
\text { symptoms or skin lesions }\end{array}$ & $\begin{array}{l}\text { Malaria, tuberculosis, hepatitis A, hepatitis B, acute hepatitis C, hepatitis E, } \\
\text { leishmaniasis, acute schistosomiasis (Katayama syndrome), amebic liver abscess, } \\
\text { leptospirosis, African trypanosomiasis, Chagas disease, viral hemorrhagic fevers, } \\
\text { Q fever, measles, typhoid fever }\end{array}$ \\
\hline$>6$ weeks & $\begin{array}{l}\text { A variety of symptoms: fever } \\
+ \text { neurological or respiratory } \\
\text { symptoms or skin lesions }\end{array}$ & $\begin{array}{l}\text { Malaria, tuberculosis, hepatitis B, acute hepatitis C, hepatitis E, leishmaniasis, } \\
\text { wuchereriasis, onchocerciasis, schistosomiasis, amebic liver abscess, African } \\
\text { trypanosomiasis }\end{array}$ \\
\hline
\end{tabular}

Table 3. Incubation period and geographic regions [12, 21]

\begin{tabular}{|c|c|c|}
\hline Incubation period & Geographic regions & Disease \\
\hline $\begin{array}{l}6-30 \text { days ( } 98 \% \text { onset within } \\
3 \text { months of travel) }\end{array}$ & $\begin{array}{l}\text { Especially in Sub-Saharan Africa (>90\%), also in Central and South } \\
\text { America, India and South-East Asia }\end{array}$ & $\begin{array}{l}\text { Malaria, Plasmodium } \\
\text { falciparum }\end{array}$ \\
\hline $\begin{array}{l}8 \text { days to } 12 \text { months ( } 50 \% \text { have } \\
\text { onset }>30 \text { days after completion } \\
\text { of travel) }\end{array}$ & $\begin{array}{l}\text { Especially in Central and South America, India and South-East Asia, } \\
\text { also in Sub-Saharan Africa }\end{array}$ & Malaria, Plasmodium vivax \\
\hline $4-8$ days (range $3-14$ days) & South-East Asia, Central and South America, Africa, Pacific islands & Dengue \\
\hline 2-4 days (range $1-14$ days) & South-East Asia, Central and South America, Africa & Chikungunya \\
\hline $3-14$ days & South-East Asia, Central and South America, Africa, Pacific islands & Zika \\
\hline$<21$ days & $\begin{array}{l}\text { Democratic Republic of the Congo (Ebola), Nigeria (Lassa); the } \\
\text { Middle East, the Balkans, Central Asia, Africa (Crimean-Congo) }\end{array}$ & Viral hemorrhagic fevers \\
\hline $2-14$ days & Arabian Peninsula & MERS-CoV \\
\hline $2-14$ days & Cosmopolitan & COVID-19 \\
\hline $1-3$ days & Cosmopolitan & Influenza \\
\hline $5-6$ days (range $2-10$ days) & Cosmopolitan & Legionellosis \\
\hline $3-8$ days & Sub-Saharan Africa, South America & Yellow fever \\
\hline $3-6$ days (range $1-20$ days) & Africa, Asia, Europe & West Nile fever \\
\hline $3-14$ days (range $1-20$ days) & South and South-East Asia (from India to Japan) & Japanese encephalitis \\
\hline $28-30$ days (range $15-50$ days) & Cosmopolitan & Hepatitis A \\
\hline 26-42 days (range 2-9 weeks) & Cosmopolitan & Hepatitis E \\
\hline $6-30$ days (range $3-60$ days) & Cosmopolitan (especially in Indian subcontinent) & Typhoid fever \\
\hline $7-14$ days & Cosmopolitan, epidemics & Epidemic typhus \\
\hline $7-12$ days (range $2-26$ days) & Cosmopolitan (especially in Asia) & Leptospirosis \\
\hline $4-8$ weeks & Sub-Saharan Africa, South-East Asia, South America & $\begin{array}{l}\text { Acute schistosomiasis } \\
\text { (Katayama syndrome) }\end{array}$ \\
\hline $\begin{array}{l}2-6 \text { months (range } 10 \text { days to } \\
\text { years) }\end{array}$ & Mediterranean, Africa, Asia, Central and South America & $\begin{array}{l}\text { Leishmaniasis (cutaneous, } \\
\text { visceral, mucocutaneous) }\end{array}$ \\
\hline
\end{tabular}


Table 4. Risk factors (exposures and activities) [21]

\begin{tabular}{|c|c|}
\hline Risk factors & Disease \\
\hline Contact with fresh water & Schistosomiasis, leptospirosis \\
\hline Contact with soil (walking barefoot) & Cutaneous larva migrans (hookworm, strongyloidiasis), tungiasis \\
\hline Contact with animals & Rabies, tularemia, Q fever, anthrax, viral hemorrhagic fevers, plaque, brucellosis \\
\hline Dairy consumption & Brucellosis, tuberculosis, shigellosis \\
\hline Non-potable water consumption & $\begin{array}{l}\text { Hepatitis A and E, typhoid fever, amebiasis, giardiasis, cryptosporidiasis, shigellosis, } \\
\text { cyclosporiasis }\end{array}$ \\
\hline Consumption of raw and undercooked food & Hepatitis A, bacterial enteric infections, trichinosis, amebiasis, toxoplasmosis, cestodiasis \\
\hline High-risk sexual contact & AIDS, hepatitis B and C, herpes, gonorrhea, syphilis \\
\hline Cave exploration & Rabies, histoplasmosis \\
\hline Contact with ill/infected patients & $\begin{array}{l}\text { Tuberculosis, invasive meningococcal disease, influenza, MERS-CoV, COVID-19, viral } \\
\text { hemorrhagic fevers }\end{array}$ \\
\hline Exposure to mosquitoes & Malaria, dengue, chikungunya, zika, yellow fever, other arboviruses, filariasis \\
\hline Exposure to tics & Rickettsioses, borreliosis, Q fever, tularemia, Crimean-Congo hemorrhagic fever \\
\hline Exposure to flies & African trypanosomiasis, leshmaniasis, onchocerciasis, bartonellosis \\
\hline Exposure to fleas & Murine typhus, plague \\
\hline Exposure to lice & Exanthematic typhus, relapsing fever \\
\hline Exposure to mites & Scrub typhus \\
\hline
\end{tabular}

diarrhea, nausea, vomiting, respiratory symptoms, urinary or genital disorders, dermatoses including jaundice, weight loss;

- asymptomatic travelers who have a chronic illness, which may increase their risk of complications of travel-related infection;

- asymptomatic travelers who are immunocompromised (an immunological disorder, or medically induced immunosuppression);

- asymptomatic travelers who have spent more than 3 months in a country with harsh climate and poor standards of sanitation;

- asymptomatic travelers who might have been exposed to risk factors (non-compliance with disease prevention measures or antimalarial chemoprophylaxis, extreme sports, unsafe sex contacts, consumption of food or water from unsafe sources, etc.) [22, 23].

\section{SYMPTOMATIC TRAVELERS}

This group of travelers frequently consults a travel medicine specialist to seek or to confirm a diagnosis established elsewhere or on their own. Another incentive to consult a physician is the fear of spreading the infection to other people (family, friends, co-workers). This is particularly important in case of airborne transmission (coronavirus infection, influenza), fecal-oral transmission (intestinal parasites, salmonellosis, shigellosis), direct contact transmission (scabies) and sexually transmitted diseases.

\section{ASYMPTOMATIC SHORT-TERM TRAVELERS}

Routine post-travel screening can be restricted to patients who report exposure to risk factors during their travel, as well as patients who are immunocompromised or have chronic conditions. For those travelling on business, a post-travel screening procedure might be required by their employer (a compulsory periodic medical evaluation in occupational medicine).

\section{ASYMPTOMATIC LONG-TERM TRAVELERS}

This group of patients will greatly benefit from a thorough medical interview to assess potential risk factors they might have been exposed to while staying in a developing country. The major risk factors will include: exposure to mosquitoes, sand flies, ticks (vector-borne diseases), exposure to contaminated freshwater (schistosomiasis, leptospirosis) or contaminated soil (tetanus, intestinal helminthiases), consumption of food or water from unsafe sources (water-and food-borne diseases), unprotected sexual contacts with casual partners (sexually transmitted diseases [STDs]), animal bites (rabies). If a specific exposure is identified, with a significant risk of infection, screening laboratory tests may be indicated.

\section{ASYMPTOMATIC EXTREME/ADVENTUROUS TRAVELERS}

When visiting countries with harsh environmental conditions adventurous travelers frequently adopt lifestyles similar to those of the local people, and therefore run a higher 
risk of developing unusual infections. Infectious diseases which have a short incubation period are likely to become symptomatic during travel. When adventurous/extreme travelers are asymptomatic, the following infections or illnesses may be suspected: schistosomiasis (bathing or swimming in contaminated freshwater lakes, ponds or rivers), histoplasmosis (exploring bat-infested caves), cutaneous larva migrans (walking barefoot in feces-contaminated soil), filariasis (mosquito bites), leishmaniasis (sand flies bites), AIDS (unprotected sex with new partners) [23].

\section{POST-TRAVEL SCREENING}

The risk of developing a travel-related health problem will depend on a variety of factors. The common risk factors usually include: the level of endemicity in the countries visited, the general health condition of a traveler (proper functioning of the immune and the thermoregulatory systems, chronic diseases), adoption of prophylactic measures, duration of travel, type of activities (a leisure holiday vs. extreme sports). In general, the risk of acquiring a travel-related disease is higher in tropical and subtropical destinations, which is associated with a higher risk of exposure to vector-borne, food and water-borne, airborne or sexually transmitted pathogens. The groups of travelers who run the highest risk of developing a travel-related illness include the elderly, young children, pregnant women, people with disabilities, patients with cancer, patients with circulatory system disorders or renal disorders, diabetic patients, patients with thyroid disease, epilepsy or psychiatric disorders. Because of the rapidly increasing numbers of international tourist arrivals and the growing number of global health risk factors, post-travel screening has become a necessity. The introduction of screening test panels targeted at specific groups of travelers (depending on the type of clinical manifestations, risk exposure, countries visited) seem to be a good solution to the problem of travel-related health assessment. The pre-travel test panel is generally recommended for tourists with a history of chronic diseases (Table 5) [24].

A detailed medical interview is the basis of the post-travel screening process. In order to establish an accurate diagnosis and implement effective treatment a health care provider will need the information on the patient's past medical history, the symptoms which have occurred during or after travel, possible risk exposures and the list of countries the patient has visited. During a post-travel follow-up a doctor may inform the patient of the common routes of transmission (especially of the infectious and parasitic diseases) as it may help the patient identify potentially risky exposures (Table 4). It is important to remember that a considerable proportion of travel-related infections might be asymptomatic (numerous parasitic diseases) and that it would be impossible to detect certain infections during the window period, i.e. the period from infection to when the body products enough antibodies to be detected by laboratory tests (the window period for human immunodeficiency virus (HIV) may be up to 12 weeks). A popular method used for screening returned travelers is to perform qualitative rapid diagnostic tests, however, when it is important to assess the intensity of the invasion (as in schistosomiasis, some filarial infections) quantitative and semi-quantitative tests will be more useful. If an asymptomatic patient seeks medical help shortly after returning from a country where infectious diseases are endemic or where there has been an outbreak of an infectious disease, or if a patient had significant risk exposure during travel, a health care provider should inform him of the necessity to report for a follow-up screening 3 months after the initial tests (to confirm or rule out infections which have longer incubation and latent periods (tuberculosis, benign tertian malaria, amebic liver abscess, acute schistosomiasis, acute HIV seroconversion) [23].

The diagnostic procedures for common tropical and cosmopolitan infections in asymptomatic travelers who have returned from tropical or subtropical destinations are presented in Table 6.

\section{BASIC LABORATORY TESTS}

A basic set of laboratory tests includes a total blood count with differential, liver enzymes levels (ALT, AST, ALP, BR, GTP), creatinine, and CRP. These tests provide general information on potential infections and systemic inflammation and are useful in detecting any changes in the blood count (leukocytosis, leukopenia, anemia, thrombocytopenia, eosinophilia) as well as any dysfunction of liver or kidney. Urinalysis, including urine microscopy and testing for proteinuria, is essential when urinary tract infection is suspected, but generally fails to provide useful information on other diseases in asymptomatic patients [12, 23].

\section{BLOOD EOSINOPHIL COUNT}

Absolute eosinophil count (i.e. calculating the number of eosinophils in peripheral blood sample) may be used to detect parasitic infections, but also some allergic or respiratory infections. Eosinophilia is defined as an increased blood eosinophil count $>4 \%$ and is usually associated with parasitic diseases, such as schistosomiasis, strongyloidosis, ascariasis, hookworm infection, trichinosis, lymphatic filarioses (wuchereriosis), cutaneous and subcutaneous filarioses (loiasis, onchocerciasis), fasciolosis. Eosinophilia is usually more pronounced when parasites migrate through the blood or tissues, as in infections caused by the migratory intestinal helminths. However, in most patients with an asymptomatic parasitic infection, the eosinophil count is normal. Eosinophilia may also be associated with some infectious diseases, e.g. HIV infections, coccidioidomycosis, aspergillosis, tuberculosis and syphilis [11, 12, 25, 26]. 
Table 5. Screening test panels recommended for travelers [24]

\begin{tabular}{|c|c|c|}
\hline No. & Screening test panel & Laboratory tests included \\
\hline 1 & Pre-travel assessment panel & $\begin{array}{l}\text { ESR, blood count with differential; urinalysis; urea, creatinine; liver enzymes } \\
\text { (ALT, AST, ALP, BR, GGTP); routine tests for chronic diseases a traveler may have }\end{array}$ \\
\hline 2 & $\begin{array}{l}\text { Post-travel assessment panel } \\
\text { (asymptomatic patients) }\end{array}$ & $\begin{array}{l}\text { ESR, blood count with differential; urinalysis, creatinine; liver enzymes (ALT, AST, ALP, BR, } \\
\text { GGTP); CRP, quantitative; multiple stool microscopy, three samples (intestinal parasites) }\end{array}$ \\
\hline 3 & $\begin{array}{l}\text { Post-travel assessment panel } \\
\text { (gastrointestinal symptoms) }\end{array}$ & $\begin{array}{l}\text { ESR, blood count with differential; liver enzymes (ALT, AST, ALP, BR, GGTP); CRP, } \\
\text { quantitative; HAV, HEV IgM/IgG; gastrointestinal panel including } 25 \text { pathogens (Norovirus, } \\
\text { Adenovirus, Sapovirus, Rotavirus, Astrovirus, STEC, EPEC, ETEC, EAEC, E. coli 0157, } \\
\text { Shigella spp., Salmonella spp., Aeromonas spp., Campylobacter spp., Clostridium difficile } \\
\text { toxin A, Yersinia enterocolitica, Vibrio spp., Dientamoeba fragilis, Blastocystis spp., } \\
\text { Cryptosporidium spp., Cyclospora cayetanensis, Giardia lamblia, Entamoeba histolytica), } \\
\text { real-time PCR; multiple stool microscopy, three samples (intestinal parasites) }\end{array}$ \\
\hline 4 & $\begin{array}{l}\text { Post-travel assessment panel } \\
\text { (respiratory symptoms) }\end{array}$ & $\begin{array}{l}\text { ESR, blood count with differential; CRP, quantitative; respiratory panel including } \\
26 \text { pathogens (Flu A, Flu B, RSV A, RSV B, Flu A-H1, Flu A-H1pdm09, Flu A-H3, Adenovirus, } \\
\text { Enterovirus, Parainfluenza virus 1,2,3,4, Metapneumovirus, Bocavirus, Rhinovirus, } \\
\text { Coronavirus NL63, 229E, OC43, Mycoplasma pneumoniae, Chlamydophila pneumoniae, } \\
\text { Legionella pneumophila, Haemophilus influenzae, Streptococcus pneumoniae, Bordetella } \\
\text { pertussis, Bordetella parapertussis), real-time PCR }\end{array}$ \\
\hline 5 & $\begin{array}{l}\text { Post-travel assessment panel } \\
\text { (fever of unknown origin) }\end{array}$ & $\begin{array}{l}\text { ESR, blood count with differential; urinalysis, urine culture (bacteriological test); CRP, } \\
\text { quantitative; malaria (Plasmodium spp.), parasitemia, blood microscopy; HAV, HEV } \\
\text { IgM/IgG; dengue IgM/IgG; chikungunya IgM/IgG; zika IgM/IgG; gastrointestinal pathogen } \\
\text { panel including } 25 \text { pathogens (see section 3), real-time PCR }\end{array}$ \\
\hline 6 & $\begin{array}{l}\text { Post-travel assessment panel } \\
\text { (exposure to risk factors: unsafe } \\
\text { sex with casual partners, injections, } \\
\text { tattooing, piercing) }\end{array}$ & $\begin{array}{l}\text { HBs Ag; HCV; HIV; syphilis (Treponema pallidum) IgM/lgG; urogenital panel (Chlamydia } \\
\text { trachomatis, Neisseria gonorrhoeae, Mycoplasma genitalium, Mycoplasma hominis, } \\
\text { Ureaplasma urealyticum, Trichomonas vaginalis), real-time PCR }\end{array}$ \\
\hline 7 & $\begin{array}{l}\text { Post-travel assessment panel } \\
\text { for travelers returning from } \\
\text { Mediterranean countries } \\
\text { (Europe, North Africa) }\end{array}$ & $\begin{array}{l}\text { HAV, HEV IgM/IgG; gastrointestinal pathogen panel including } 25 \text { pathogens (see section 3), } \\
\text { real-time PCR; dengue IgM/IgG; chikungunya IgM/lgG; zika IgM/lgG; urine culture } \\
\text { (bacteriological test); multiple stool microscopy, three samples (intestinal parasites) }\end{array}$ \\
\hline 8 & $\begin{array}{l}\text { Post-travel assessment panel for } \\
\text { travelers returning from Sub-Saharan } \\
\text { Africa, South and South-East Asia }\end{array}$ & $\begin{array}{l}\text { Malaria (Plasmodium spp.) parasitemia, blood microscopy; HAV, HEV IgM/lgG; } \\
\text { gastrointestinal pathogens panel including } 25 \text { pathogens (see section 3), real-time PCR; } \\
\text { dengue IgM/lgG; chikungunya IgM/lgG; zika lgM/lgG; urine culture (bacteriological test); } \\
\text { multiple stool microscopy, three samples (intestinal parasites) }\end{array}$ \\
\hline 9 & $\begin{array}{l}\text { Post-travel assessment panel for } \\
\text { travelers returning from Central } \\
\text { America/the Caribbean or South } \\
\text { America }\end{array}$ & $\begin{array}{l}\text { Malaria (Plasmodium spp.) parasitemia, blood microscopy; HAV, HEV IgM/lgG; } \\
\text { gastrointestinal pathogens panel including } 25 \text { pathogens (see section 3), real-time PCR; } \\
\text { dengue IgM/lgG; chikungunya IgM/lgG; zika lgM/lgG; urine culture (bacteriological test); } \\
\text { multiple stool microscopy, three samples (intestinal parasites) }\end{array}$ \\
\hline
\end{tabular}

ALP - alkaline phosphatase; ALT - alanine aminotransferase; AST - aspartate aminotransferase; BR - bilirubin; CRP - C-reactive protein; ESR - erythrocyte sedimentation rate; GGTP - gamma glutamyl transpeptidase; HAV - hepatitis A virus; HEV - hepatitis E virus; HCV - hepatitis C virus; HIV - human immunodeficiency virus; $\mathrm{PCR}$ - polymerase chain reaction

\section{ABDOMINAL ULTRASOUND}

The test may be considered as a secondary diagnostic procedure in asymptomatic travelers presenting with abnormal liver and/or renal function tests and/or abnormal urinalysis [23].

\section{RESTING ELECTROCARDIOGRAM}

The test may be useful in identifying patients with the 'long QT' syndrome, who are at a higher risk of malignant ventricular tachycardia when treated with antimalarial medications (quinine, quinidine). Electrocardiogram can also help detect atrioventricular conduction problems, which are a contraindication to the use of mefloquine [23].

\section{INTESTINAL PARASITIC DISEASES}

Travelers returning from developing countries where intestinal parasitoses are endemic should be screened for parasitic infections (travelers may transmit the infection to others, even if they are asymptomatic). To establish an accurate diagnosis, it is essential to select the most reliable diagnostic method; the 'gold standard' for the diagnosis of intestinal parasitic infections is multiple stool microscopy using different techniques (direct smear, flotation, sedimentation). To differentiate between similar parasitic species (e.g. the pathogenic Entamoeba histolytica from non-pathogenic Entamoeba dispar) molecular techniques are recommended (PCR) [11, 27, 28]. 
Table 6. Diagnostics of common travel-related infections in asymptomatic travelers [23]

\begin{tabular}{|c|c|c|c|}
\hline Disease & Incubation period & Diagnostic procedure & $\begin{array}{l}\text { Time lapse after which } \\
\text { asymptomatic infection } \\
\text { becomes very unlikely } \\
\text { (given negative screen) }\end{array}$ \\
\hline Amebiasis & Days - > 6 months & $\begin{array}{l}\text { Stool microscopy (infection with E. histolytica/E. dispar) } \\
\text { Stool PCR for Entamoeba histolytica, serum antibody test } \\
\text { (infection E. histolytica, tissue invasion E. histolytica) }\end{array}$ & $\begin{array}{l}6 \text { months (may be longer, } \\
\text { even years) }\end{array}$ \\
\hline $\begin{array}{l}\text { Malaria } \\
\text { (P. falciparum) }\end{array}$ & $9-30$ days & $\begin{array}{l}\text { Thick film, malaria antigen test (parasitemia in semi-immune) } \\
\text { HRP-2 antigen test (confirmation of recent infection/diseases) } \\
\text { Serum antibody test (post-infection confirmation and chronic } \\
\text { suppressed infection) }\end{array}$ & $\begin{array}{l}\text { Non-immunes: } 3 \text { months } \\
\text { Semi-immunes: } 4 \text { years }\end{array}$ \\
\hline $\begin{array}{l}\text { Malaria } \\
\text { (P. vivax, P. ovale, } \\
\text { P. malariae) }\end{array}$ & 8 days - > 12 months & $\begin{array}{l}\text { Thick film, malaria antigen test (active infection/disease) } \\
\text { Serum antibody test } P \text {. vivax, } P \text {. ovale (post-infection } \\
\text { confirmation; interspecies cross reactions can occur) }\end{array}$ & $\begin{array}{l}\text { Benign } P \text {. vivax, } P \text {. ovale: } \\
\text { 2-4 years } \\
P . \text { malariae: }>10 \text { years }\end{array}$ \\
\hline Typhoid fever & $\begin{array}{l}7-18 \text { days } \\
\text { (range } 3-60 \text { days) }\end{array}$ & $\begin{array}{l}\text { Stool culture (convalescent carrier state) } \\
\text { Serum antibody test Widal (negative test excludes recent } \\
\text { infection, poor specificity) }\end{array}$ & 2 months \\
\hline Tuberculosis & $>30$ days & $\begin{array}{l}\text { Tuberculin test (asymptomatic infection) } \\
\text { IGRA (asymptomatic infection in BCG vaccinees) }\end{array}$ & $\begin{array}{l}2-4 \text { months (asymptomatic } \\
\text { infection - risk lifelong) }\end{array}$ \\
\hline Schistosomiasis & $14->60$ days & Serum antibody test (asymptomatic infection) & $\begin{array}{l}3-6 \text { months } \\
\text { (exceptionally longer) }\end{array}$ \\
\hline $\begin{array}{l}\text { Intestinal } \\
\text { helminths }\end{array}$ & $3->60$ days & Stool microscopy (active infection) & 2 months \\
\hline $\begin{array}{l}\text { Filariasis } \\
\text { (Wuchereria } \\
\text { bancrofti) }\end{array}$ & ? - > 12 months & $\begin{array}{l}\text { Serum antibody test (exposure or active infection) } \\
\text { Serum antigen test (active infection) } \\
\text { Nocturnal microfilaremia (active infection) }\end{array}$ & Up to 2 years \\
\hline $\begin{array}{l}\text { Filariasis } \\
\text { (Onchocerca } \\
\text { volvulus) }\end{array}$ & $3->15$ months & $\begin{array}{l}\text { Serum antibody test (exposure; low sensitivity) } \\
\text { Ocular microfilaria (active infection; requires } \\
\text { ophthalmologic examination) }\end{array}$ & Up to 2 years \\
\hline Filariasis (Loa loa) & ? - > 12 months & $\begin{array}{l}\text { Serum antibody test (exposure or active infection) } \\
\text { Daytime microfilaremia (active infection) }\end{array}$ & Up to 2 years \\
\hline Strongyloidiasis & 7 - > 21 days & $\begin{array}{l}\text { Serum antibody test (exposure, active infection; } \\
\text { sensitive, non-specific) } \\
\text { Stool microscopy (concentration technique) } \\
\text { or stool PCR or antigen test (active infection) }\end{array}$ & 1 month \\
\hline HIV & $14->90$ days & $\begin{array}{l}\text { Serum antigen/antibody test HIV-ELISA/p-24 } \\
\text { (active infection: screening) }\end{array}$ & 6 weeks -6 months \\
\hline Syphilis & 9 - > 90 days & $\begin{array}{l}\text { VDRL (active infection) } \\
\text { TPHA, FTA (confirmation, post-exposure, post-treatment) }\end{array}$ & 3 months \\
\hline Hepatitis B & $\begin{array}{l}90 \text { days } \\
\text { (range } 2-6 \text { months) }\end{array}$ & $\begin{array}{l}\text { Serum antigen test HBsAg (active or latent infection/disease) } \\
\text { Serum antibody test HBsAb, HBV DNA (immunity, } \\
\text { classification of infection activity) }\end{array}$ & 6 months \\
\hline Hepatitis C & 2 weeks -6 months & $\begin{array}{l}\text { Serum antibody test (active or latent infection/disease) } \\
\text { HCV RNA (confirmation of active infection) }\end{array}$ & 6 months \\
\hline $\begin{array}{l}\text { Chagas disease } \\
\text { (Trypanosoma } \\
\text { cruzi) }\end{array}$ & $5-14$ days & $\begin{array}{l}\text { Serum antibody test (latent or active infection) } \\
\text { PCR (active infection) }\end{array}$ & $\begin{array}{l}\text { To be followed up } \\
\text { serologically until } 6 \text { months } \\
\text { after possible exposure }\end{array}$ \\
\hline
\end{tabular}

BCG - Bacillus Calmette-Guerin; CRP - C-reactive protein; FTA - fluorescent treponemal antibody absorption; HBV DNA - hepatitis B virus DNA; HCV RNA - hepatitis B virus RNA; HRP-2 - histidine-rich protein 2; GGTP - gamma glutamyl transpeptidase; HIV - human immunodeficiency virus; IGRA - interferon-gamma release assay; PCR - polymerase chain reaction; TPHA - treponema pallidum hemagglutination assay; VDRL - venereal disease research laboratory test 


\section{SEXUALLY TRANSMITTED DISEASES}

Post-travel screening is recommended in travelers with a history of unprotected sexual contacts with casual partners (including commercial sex workers). It should involve detection of HIV, syphilis, gonorrhea, chlamydiasis, hepatitis B and C, genital herpes (HSV), condylomata acuminata (HPV), and tropical STDs (e.g. chancroid). In patients returning from endemic regions the medical interview will be the foundation of the post-travel screening process (a physician should consider the time of exposure, the incubation period and the window period, as in HIV infection) [29]. The PCR tests for gonorrhea or chlamydiasis may be performed on urine samples [30]. Travelers who received blood transfusions during their stay in developing countries, where blood screening procedures are often less complete, should be tested for AIDS, syphilis, hepatitis B and C [23].

\section{CONCLUSIONS}

A medical interview by an experienced physician forms the basis of the post-travel screening process both in symptomatic as well as asymptomatic travelers. The interview should primarily focus on identifying exposure to risk factors (endemic infectious diseases, failure to adopt disease prevention measures, consumption of food or water from unsafe sources, insect bites, animal bites, travelling in large groups, unsafe sex with casual partners). While physical examination (identification of abnormalities) and a well-chosen set of diagnostic tests (identification of pathogens) can be useful to detect illnesses and asymptomatic infections as well as assess the general health condition of a patient and his immune status.

\section{REFERENCES}

1. World Tourism Organization. World Tourism Barometer $\mathrm{N} 18$ January 2020. https://www.unwto.org/world-tourism-barometer-n18-january-2020 (Accessed: 30 May 2020).

2. World Tourism Organization. UNWTO Report May 2020. https:// www.unwto.org/news/covid-19-international-tourist-numbers-couldfall-60-80-in-2020 (Accessed: 30 May 2020).

3. World Tourism Organization. International Tourism Highlights. 2019 Edition. https://www.unwto.org (Accessed: 30 May 2020).

4. Worldometer. COVID-19 Coronavirus Pandemic. https://www. worldometers.info/coronavirus/ (Accessed: 29 May 2020).

5. Phelan A. COVID-19 immunity passports and vaccination certificates: scientific, equitable, and legal challenges. Lancet. 2020; 395(10237): 1595-1598, doi: 10.1016/s0140-6736(20)31034-5.

6. Simpson S, Kaufmann M, Glozman V, et al. Disease X: accelerating the development of medical countermeasures for the next pandemic. Lancet Infectious Diseases. 2020; 20(5): e108-e115, doi: 10.1016/s1473-3099(20)30123-7.

7. Narodowy Instytut Zdrowia Publicznego - Państwowy Zakład Higieny. Informacje o zachorowaniach na choroby zakaźne i zatruciach w Polsce w 2019 roku. http://wwwold.pzh.gov.pl/oldpage/epimeld/2019/index_mp.html (Accessed: 30 May 2020).
8. Korzeniewski K, Konior M, Augustynowicz A, et al. Detection of Giardia intestinalis infections in Polish soldiers deployed to Afghanistan. Int Marit Health. 2016; 67(4): 243-247, doi: 10.5603/ IMH.2016.0043, indexed in Pubmed: 28009386.

9. Korzeniewski K, Osińska J, Korsak J, et al. Hepatitis E virus seroprevalence in Polish soldiers serving in harsh environmental conditions. Int Marit Health. 2018; 69(2): 137-141, doi: 10.5603/ IMH.2018.0020, indexed in Pubmed: 29939391.

10. Angelo KM, Kozarsky PE, Ryan ET, et al. What proportion of international travellers acquire a travel-related illness? A review of the literature. J Travel Med. 2017; 24(5), doi: 10.1093/jtm/tax046, indexed in Pubmed: 28931136.

11. Korzeniewski K. Travel medicine in medical practice [in Polish]. Travel Medicine: Gdynia. 2019: 34-36.

12. Fairley JK. General approach to the returned traveler. In: Brunette GW, Nemhauser JB (Ed). CDC Yellow Book 2020. Health Information for International Travel. Oxford University Press, New York 2019: 603-609.

13. Lachish T, Van Go, Schwartz E. The returning traveler. In: Zuckerman JN, Brunette G, Leggat P (Ed). Essential travel Medicine. Wiley Blackwell, Oxford 2015: 313-326.

14. Torresi J, McGuinness S, Leder K, O'Brien D, Ruff T, Starr M, Gibney K. Manual of Travel Medicine. Fourth Edition. Springer, Singapore 2019: 377-391.

15. Freedman DO, Weld LH, Kozarsky PE, et al. GeoSentinel Surveillance Network. Spectrum of disease and relation to place of exposure among ill returned travelers. N Engl J Med. 2006; 354(2): 119-130, doi: 10.1056/NEJMoa051331, indexed in Pubmed: 16407507.

16. Fedor A, Bojanowski I, Korzeniewski K. Gastrointestinal infections in returned travelers. Int Marit Health. 2019; 70(4): 244-251, doi: 10.5603/IMH.2019.0039, indexed in Pubmed: 31891179.

17. Korzeniewski K, Juszczak D, Jerzemowski J. Skin lesions in returning travellers. Int Marit Health. 2015; 66(3): 173-180, doi: 10.5603/ IMH.2015.0034, indexed in Pubmed: 26394319.

18. Korzeniewski K, Nitsch-Osuch A, Lass A, et al. Respiratory infections in travelers returning from the tropics. Adv Exp Med Biol. 2015; 849: 75-82, doi: 10.1007/5584_2014_89, indexed in Pubmed: 25381557.

19. Korzeniewski K, Gaweł B, Krankowska D, et al. Fever of unknown origin in returning travellers. Int Marit Health. 2015; 66(2): 77-83, doi: 10.5603/IMH.2015.0019, indexed in Pubmed: 26119676.

20. Korzeniewski K. Travel Medicine. Compendium. PZWL Medical Publishing House, Warsaw 2016: 314-315.

21. Jiménez-Morillas F, Gil-Mosquera M, García-Lamberechts EJ, et al. INFURG-SEMES tropical diseases department. Fever in travellers returning from the tropics. Med Clin (Engl Ed). 2019; 153(5): 205-212, doi: 10.1016/j.medcle.2019.03.013, indexed in Pubmed: 32289079.

22. Libman M, Barkati S. Screening asymptomatic returned travelers. In: Brunette GW, Nemhauser JB (Ed). CDC Yellow Book 2020. Health Information for International Travel. Oxford University Press, New York 2019: 610-615.

23. Clerinx J, Hamer D, Libman M. Posttravel screening. In: Keystone JS, Kozarsky PE, Connor BA, Northdurft HD, Mendelson M, Leder K. Travel Medicine. Fourth Edition. Elsevier Inc., USA 2019: 487-494.

24. Korzeniewski K. Medical traveler's toolkit. Travel Medicine, Gdynia 2020: 20-22.

25. O'Connell EM, Nutman TB. Eosinophilia in infectious diseases. Immunol Allergy Clin North Am. 2015; 35(3): 493-522, doi: 10.1016/j. iac.2015.05.003, indexed in Pubmed: 26209897. 
26. Ustianowski A, Zumla A. Eosinophilia in the returning traveler. Infect Dis Clin North Am. 2012; 26(3): 781-789, doi: 10.1016/j. idc.2012.05.004, indexed in Pubmed: 22963783.

27. Yansouni CP, Merckx J, Libman MD, et al. Recent advances in clinical parasitology diagnostics. Curr Infect Dis Rep. 2014; 16(11): 434, doi: 10.1007/s11908-014-0434-9, indexed in Pubmed: 25230603.

28. Momčilović S, Cantacessi C, Arsić-Arsenijević V, et al. Rapid diagnosis of parasitic diseases: current scenario and future needs. Clin Microbi- ol Infect. 2019; 25(3): 290-309, doi: 10.1016/j.cmi.2018.04.028, indexed in Pubmed: 29730224.

29. Korzeniewski K, Juszczak D. Travel-related sexually transmitted infections. Int Marit Health. 2015; 66(4): 238-246, doi: 10.5603/ IMH.2015.0045, indexed in Pubmed: 26726895.

30. Matteelli A, Schlagenhauf P, Carvalho A, et al. Travel-associated sexually transmitted infections: an observational cross-sectional study of the GeoSentinel surveillance database. Lancet Infectious Diseases. 2013; 13(3): 205-213, doi: 10.1016/s1473-3099(12)70291-8. 